\title{
FORUM
}

\section{The importance of recognising and conserving biological diversity: a reply to Dussex et al. (2018)}

\author{
Nicolas J. Rawlence ${ }^{1 *}$ and Jonathan M. Waters ${ }^{1 *}$ \\ ${ }^{1}$ Otago Palaeogenetics Laboratory, Department of Zoology, University of Otago, PO Box 56, Dunedin 9054, New Zealand \\ *Authors for correspondence (Email: nic.rawlence@otago.ac.nz; jon.waters@otago.ac.nz)
}

Published online: 21 May 2018

In their recent article, Dussex et al. (2018) draw attention to some current issues in New Zealand avian systematics, and particularly the difficulties that can potentially arise in cases where molecular and morphological data prove difficult to reconcile. These researchers call for integrative approaches to avian systematics, to overcome the limitations of singlemethod studies, and we wholeheartedly agree with this common-sense view. Additionally, while taxonomic studies at shallow phylogenetic levels may struggle to capture dynamic evolutionary processes, multiple forms of concordant data can provide a strong basis for recognising and conserving recently-evolved biological diversity.

Given Dussex et al.'s (2018) plea for avian taxonomy to be grounded in multiple sources of non-conflicting data, we were surprised to read their criticism of a recent study that used precisely the type of integrative approach that these authors seem to advocate. Specifically, Dussex et al. (2018) take issue with Rawlence et al.'s (2017) recent recognition of extinct New Zealand swan (Cygnus spp.) taxa, despite the fact that Rawlence et al.'s (2017) recommendations were based on congruent findings from both morphological and genetic data analyses (Fig. 1). Dussex et al.'s (2018) statements that "This example...demonstrates a preference for one type of data when it tells a more exciting story" and "at least three papers [Rawlence et al. (2017) included]...exemplify the issues inherent in ignoring inconvenient lines of evidence for species classification" seem to question the scientific integrity of Rawlence et al. (2017). In particular, the allegation that Rawlence et al. (2017) misrepresented evidence by showing bias towards a particular dataset is bewildering, especially given that Cygnus molecules and morphology yielded patterns that were completely congruent (Fig. 1). Unfortunately, Dussex et al. (2018) provide no data or analyses to substantiate their seemingly inaccurate allegations of incongruence ("When genetic and phenotypic data do not agree"). In our view, the 'lines of evidence' presented in Rawlence et al.'s (2017)

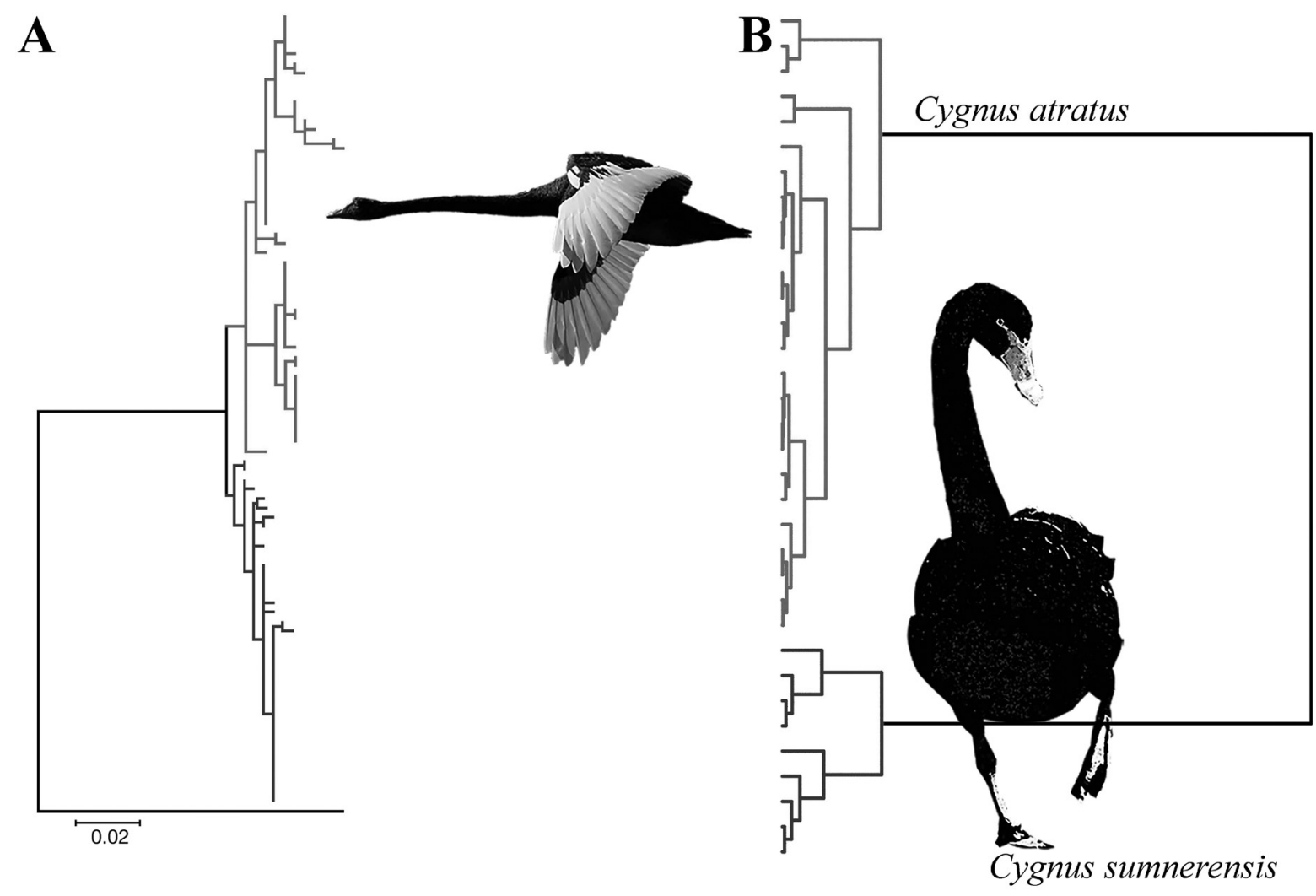

Figure 1. Reciprocal monophyly of Australian Black Swan (Cygnus atratus; red) and Poūwa (C. sumnerensis; blue) for mtDNA control region/D-loop (A); and congruent morphological clustering (B) of these taxa, based on data from Rawlence et al. (2017). 
paper were neither conflicting, inconvenient nor ignored. Cygnus atratus and C. sumnerensis, like many close pairs of avian sister taxa (see below), are clearly supportable under both phylogenetic (Cracraft 1983) and diagnosable (Baum \& Donoghue 1995; Helbig et al. 2002; Patten \& Unitt 2002; Issac et al. 2004; Cicero \& Johnson 2006; Gill et al. 2010) species concepts, the latter designed to specifically avoid taxonomic overinflation (in addition to the integrative taxonomic approaches apparently advocated by Dussex et al. (2018)).

It is possible that Dussex et al. (2018) are primarily taking issue with the depth of mtDNAdifferentiation detected between the extant Australian C. atratus and extinct New Zealand C. sumnerensis, whereby Rawlence et al. (2017) "proceed to declare a new species of swan based on 1.4\% divergence". Apparently, in their view, $1.4 \% \mathrm{mtDNA}$ divergence (regardless of any other biological differentiation) is simply too small to merit species-level recognition. On the same simplistic grounds, Dussex et al.'s (2018) implied approach could similarly see the rejection of Haast's Eagle as a distinct taxon (see below), which would make this bird one highly polymorphic species indeed, ranging in size from 1-15 kg (Bunce et al. 2005). By focusing here on the importance of absolute mtDNA divergence, Dussex et al. (2018) are seemingly advocating for a narrow 'barcoding' approach to avian taxonomy (see Hebert et al. 2004), even implying that mtDNA divergence is somehow a reliable proxy for reproductive isolation (e.g. their Fig. 1) under the Biological Species Concept (BSC) (Mayr 1940, 1966). Through their suggestion that some arbitrary minimum level of mtDNA divergence is needed to delimit species (regardless of taxonomic group?), Dussex et al. (2018) seem to have contradicted the 'integrative' approach favoured elsewhere in their article.

For the sake of context, we feel it is informative here to offer some examples of unique avian lineages from New Zealand and elsewhere that, to our knowledge, are widely accepted as taxonomically distinct (see Gill et al.2010), despite their small mtDNAdivergences (across various sequence regions) relative to sister taxa. Such taxa include Haast's Eagle (Aquila moorei; $1.25 \%$ (cyt $b$ ) divergent from closest Australian sister taxa; Bunce et al. 2005); Black Stilt (Himantopus novaezelandiae; 5\% (CR) divergent from H. leucocephalus; MacAvoy \& Chambers 1999); Takahe (Porphyrio hochstetteri; 1.3\% (12S) and 3.7\% (cyt $b$ ) divergent from P. melanotus; Trewick 1997); New Zealand/Chatham Islands Coot (Fulica prisca/ chathamensis; $0.5 \%(12 \mathrm{~S})$ divergent from $F$. atra australis; Trewick 1997); New Zealand Quail (Coturnix novaezelandiae; $3 \%$ (COI) divergent from C. pectoralis; Seabrook-Davison et al. 2009); New Zealand Pigeon (Hemiphaga novaeseelandiae novaeseelandiae; up to $1.3 \%$ (cyt $b$ ) and up to $2.9 \%$ (CR) divergent from $H$. n. spadicea and $H$. chathamensis; Goldberg et al. 2011); and, Waitaha Penguin (Megadyptes waitaha; 2.2-4.3\% (CR) divergent from $M$. antipodes; Boessenkool et al. 2009). Additionally, a substantial proportion of recognized avian taxa have yet to evolve mtDNA monophyly or reproductive isolation (e.g. Grant \& Grant 1992, 1997; Kerr et al. 2007; Joseph \& Omland 2009), further questioning the utility of one-dimensional barcoding approaches or strict reliance on the BSC (Mayr 1940,1966). Overall, it is clear that distinct taxa can evolve over rapid evolutionary timeframes (e.g. Mendelson \& Shaw 2005; Lerner et al. 2011; Keller et al. 2012). Thus, it seems highly misguided to impose arbitrary, minimum mtDNA divergences for species delimitation, while ignoring other forms of data (see Lambert et al. $2005 \mathrm{cf}$. integrative approach of Bunce et al. 2009).
Dussex et al. (2018) stress that researchers should seek to assess "both neutral and selective genetic diversity when delineating taxa", although it is unclear which of these they consider to be more important in taxonomic terms. We agree that genome-wide approaches provide the best evidence for informing all types of biological research, but also note that selection at one or a few loci can generate the illusion of taxonomic diversity (e.g. Veale et al. 2018). For instance, there are several cases in which populations previously recognised by avian systematists as distinct (e.g. based on a single plumage characteristic) are not distinctive for genome-wide data (e.g. Banks Peninsula populations of Eudyptula minor; Grosser et al. 2015). Thus there is a risk that focussing on one or a few loci under selection may result in taxonomic over-splitting, something Dussex et al. (2018) seem to be advocating against.

While we agree with Dussex et al. (2018) that sound scientific data and analyses are required to underpin conservation policy, some of the seemingly contradictory viewpoints presented by these authors seem to amount to little more than a plea for 'no more species', as though political, pragmatic or 'on the ground' considerations should be allowed to override the best scientific evidence. We would prefer to see conservation informed by the strongest data available, with continued and increasing emphasis on genome-wide and integrative approaches designed to recognise and prioritise diversity (e.g. Narum et al 2013; Shafer et al 2015). While the relevance of particular species concepts may be context-dependent, for the purpose of conserving biodiversity, we believe it is critical that scientists seek to recognise evolutionary/ecologically significant diversity, rather than seeking to discredit conservation-status arguments for taxa that might be disputable under, for instance, barcoding approaches or the BSC.

In summary, while there are indeed major challenges ahead for conservation of endangered native taxa and populations, we are concerned that newly-recognized biodiversity (e.g. Weston et al. 2015; Grosser et al. 2016; Weir et al. 2016) not be dismissed as an 'inconvenient truth'. It is particularly concerning to us that Dussex et al. (2018) seem to imply that agnostic ("cautious") approaches (whereby newly-recognised, highly-distinct lineages are not afforded separate taxonomic status, e.g. Weston et al. 2015; Weir et al. 2016) are somehow preferable to studies that make more definitive taxonomic and conservation recommendations. Rather than representing a genuinely progressive view, the "caution" advocated by Dussex et al. (2018) carries the real risk that important biodiversity could become extinct before it is prioritised for conservation (e.g. Robertson et al. 2017; Wright 2017). In our view, such an agnostic approach to taxonomy is anything but "cautious".

\section{Acknowledgments}

We thank Martyn Kennedy, Hamish Spencer, and two anonymous reviewers, for helpful discussions and comments on this manuscript. NJR is supported by a Royal Society of New Zealand Marsden Grant.

\section{References}

Baum DA, Donoghue MJ 1995. Choosing among alternative "phylogenetics" species concepts. Systematic Botany 20: 560-573.

Boessenkool S, Austin JJ, Worthy TH, Scofield RP, Cooper A, 
Seddon PJ, Waters JM2009. Relict of colonizer? Extinction and range expansion of penguins in southern New Zealand. Proceedings of the Royal Society B: Biological Sciences 276: 815-821.

Bunce M, Szulkin M, Lerner HRL, Barnes I, Shapiro B, Cooper A, Holdaway RN 2005. Ancient DNA provides new insights into the evolutionary history of New Zealand's extinct giant eagle. PLoS Biology 3: e9.

Bunce M, Worthy TH, Phillips MJ, Holdaway RN, Willerslev E, Haile J, Shapiro B, Scofield RP, Drummond A, Kamp PJJ, CooperA2009. The evolutionary history of the extinct ratite moa and New Zealand Neogene paleogeography. Proceedings of the National Academy of Science of the United States of America 106: 20646-20651.

Cicero C, Johnson NK 2006. Diagnosability of subspecies: lessons from sage sparrows (Amphispiza belli) for analysis of geographical variation in birds. Auk 123: 266-274.

Cracraft J 1983. Species concepts and speciation analysis. Current Ornithology 1: 159-187.

Dussex N, Taylor HR, Irestedt M, Robertson BC 2018. When genetic and phenotypic data do not agree: the conservation implications of ignoring inconvenient taxonomic evidence. New Zealand Journal of Ecology 42: 284-290.

Gill BJ, Bell BD, Chambers GK, Medway DG, Palma RL, Scofield RP, Tennyson AJD, Worthy TH 2010. Checklist of the birds of New Zealand, Norfolk and Macquarie Islands, and the Ross Dependency Antarctica. 4th edn. Wellington, Te Papa Press in association with the Ornithological Society of New Zealand.

Goldberg J, Trewick SA, Powlesland RG 2011. Population structure and biogeography of Hemiphaga pigeons (Aves: Columbidae) on islands in the New Zealand region. Journal of Biogeography 38: 285-298.

Grant PR, Grant BR. 1992 Hybridization of bird species. Science 256: 193-197.

Grant PR, Grant BR 1997. Genetics and the origin of bird species. Proceedings of the National Academy of Sciences of the United States of America 94: 7768-7775.

Grosser S, Burridge CP, Peucker AJ, Waters JM 2015. Coalescent modelling suggests recent secondary-contact of cryptic penguin species. PLoS One 10: e0144966.

Grosser S, Rawlence NJ, Anderson CNK, Smith IWG, Scofield RP, Waters JM 2016. Invader or resident? Ancient-DNA reveals rapid species turnover in New Zealand little penguins. Proceedings of the Royal Society B: Biological Sciences 283: 20152879.

Hebert PDN, Stoeckle MY, Zemlak TS, Francis CM 2004. Identification of birds through DNA barcodes. PLoS Biology 2: e312.

HelbigAJ, KnoxAG, Parkin DT, Sangster G, Collinson M2002. Guidelines for assigning species rank. Ibis 144: 518-525.

Issac NJB, Mallet J, Mace GM 2004. Taxonomic inflation: its influence on macroecology and conservation. Trends in Ecology and Evolution 19: 464-469.

Joseph L, Omland KE2009. Phylogeography: its development and impact in Australo-Papuan ornithology with special reference to paraphyly in Australian birds. Emu: Austral Ornithology 109: 1-23.

Keller I, Wagner CE, Greuter L, Mwaiko S, Selz OM, Sivasundar A, Wittwer S, Seehausen O 2012. Population genomic signatures of divergent adaptation, gene flow and hybrid speciation in the rapid radiation of Lake Victoria cichlid fishes. Molecular Ecology 22: 2848-2863.

Kerr KCR, Stoeckle MY, Dove CJ, Weigt LA, Francis CM,
Hebert PDN 2007. Comprehensive DNA barcode coverage of North American birds. Molecular Ecology Notes 7: 535-543.

Lambert DM, Baker A, Huynen L, Haddrath O, Hebert PD, Miller CD 2005. Is a large-scale DNA-based inventory of ancient life possible? Journal of Hereditary 96: 279-284.

Lerner HR, Meyer M, James HF, Hofreiter M, Fleischer RC 2011. Multilocus resolution of phylogeny and timescale in the extant adaptive radiation of Hawaiian honeycreepers. Current Biology 21: 1838-1844.

MacAvoy ES, Chambers GK 1999. Mitochondrial DNA sequence from black and pied stilts. Science for Conservation 105: 15-29.

Mayr E 1940. Speciation phenomena in birds. The American Naturalist 74: 249-278.

Mayr E 1996. What is species and what is not? Philosophy of Science 63: 261-276.

Mendelson TC, Shaw KL 2005. Rapid speciation in an arthropod. Nature 433: 375-376.

Narum SR, Buerkle CA, Davey JW, Miller MR, Hohenlohe PA 2013. Genotyping-by-sequencing in ecological and conservation genomics. MolecularEcology 22:2841-2847.

Patten MA, Unitt P 2002. Diagnosability versus mean differences of sage sparrow subspecies. Auk 119: 26-35.

Rawlence NJ, KardamakiA, Easton LJ, Tennyson AJD, Scofield RP, Waters JM 2017. Ancient DNA and morphometric analysis reveal extinction and replacement of New Zealand's unique black swans. Proceedings of the Royal Society B: Biological Sciences 284: 20170876.

Robertson HA, Baird K, Dowding JE, Elliott GP, Hitchmough RA, Miskelly CM, McArthur N, O’Donnell CFJ, Sagar PM, Scofield RP, Taylor GA 2017. Conservation status of New Zealand birds, 2016. New Zealand Threat Classification Series 19. Wellington, Department of Conservation.

Seabrook-Davison M, Huynen L, Lambert DM, Brunton DH 2009. Ancient DNA resolves identity and phylogeny of New Zealand's extinct and living quail. PLoS ONE 4: e6400.

Shafer AB, Wolf JB, Alves PC, Bergstrom L, Bruford MW, Brannstrom I, Colling G, Dalen L, De Meester L, Ekblom R etal. 2015. Genomics and the challenging translation into conservation practice. Trends in Ecology and Evolution 30: 78-87.

Trewick SA 1997. Flightlessness and phylogeny amongst endemic rails (Aves: Rallidae) of the New Zealand region. Philosophical Transactions of the Royal Society of London B; Biological Sciences 352: 429-446.

VealeAJ, Foster BJ, Dearden PK, Waters JM 2018. Genotypingby-sequencing supports a genetic basis for alpine wingreduction in a New Zealand stonefly. bioRxiv: 264473.

Weir JT, Haddrath O, Robertson HA, Colbourne RM, Baker AJ 2016. Explosive ice age diversification of kiwi. Proceedings of the National Academy of Sciences of the United States of America 113: 5580-5587.

Weston KA, Robertson BC 2015. Population structure within an alpine archipelago: strong signature of past climate change in the New Zealand rock wren (Xenicus gilviventris). Molecular Ecology 24: 4778-4794.

Wright J 2017. Taonga of an island nation: saving New Zealand's birds. Wellington, Parliamentary Commissioner for the Environment.

Received 9 March 2018; accepted 10 May 2018

Editorial board member: Jamie Wood 